\title{
Experience the Future in Full-Scale: Technological Background Relations and Visions of The Good Society at the World's Columbian Exposition
}

Keywords: the good society, political philosophy, technology, sociotechnical imaginaries, public world, the Gilded Age.

Abstract: Do we have any means of predicting or evaluating how technological developments could contribute to a good society before they become part of everyday life? This paper turns to history for a potential answer by seeing the 1893 World's Columbian Exposition as one example of a tentative materialization of a vision of the good society supported by technological systems and artifacts. The first part of the paper provides a theoretical framework for understanding the communication of private sociotechnical visions of the good society to the public by way of full-scale models, and addresses how to evaluate such visions. Based on this framework, the paper explores the Exposition as a sociotechnical prototype, publicly enacted and experienced, and essential to insights about our own sociotechnical future.

This research did not receive any specific grant from funding agencies in the public, commercial, or not-for-profit sectors.

\section{Introduction}

Around midday on May 1, 1893 American President Grover Cleveland stood before a crowd of nearly 130,000 at the center of the White City, which formed the main display of the World's Columbian Exposition in Chicago, and declared in his opening speech that as "this vast Exposition is set in motion, so at the same instant let our hopes and aspirations awaken forces which in all time to come shall influence the welfare, the dignity and the freedom of mankind." At 12:20 he placed his hand on a button made of gold and ivory that by a single push released a "magic current of electricity," which "opened the valve of the greatest of engines and breathed life into the cylinders and wheels of that monster industrial servant." As the Exposition's engines, fountains and steam whistles were brought to life, it instilled a sense of "thrill and power and conquest through the hearts of the multitude, through all civilization... and the crowd shouted again and again."

President Cleveland's single push of a button symbolized technological mastery. This illusion however occurred upon a carefully set stage envisioned by the Exposition's Director of Works, Daniel H. Burnham, and constructed by his team of engineers and architects. In-between its white neo-classical buildings and its carefully

\footnotetext{
${ }^{1}$ Board of Control, World's Columbian Exposition Chicago, Dedicatory and opening ceremonies of the World's Columbian exposition: Historical and Descriptive. (Chicago: Stone, Kastler \& Painter, 1893 $39,265,259,266$.
} 
sculpted landscape lay a vast network of dynamos, steam engines, cables, piping and steel girders.

The White City of the World's Columbian Exposition was a tentative materialization of Burnham's vision of technology and the good society. It came as a response to the turbulent socioeconomic context sardonically referred to as the Gilded Age, a period marked by rapid industrialization, mechanized farming and agricultural overproduction, the growth of urban centers and urban decay, increased immigration and a series of economic panics. ${ }^{2}$ In contrast, the White City gave its visitors the chance to experience, in full-scale, a version of the good society by establishing a harmonious relationship between industry, technology, culture and architecture. During the six months that it was open, the Exposition would sell over 27 million tickets. ${ }^{3}$ Within a little over a year its temporary structures had been lost to fires. Burnham would go on to become the leading figure in the influential, but short-lived, American City Beautiful Movement, which sought to extend the Exposition's vision into American cities and society.

The predominant interpretation of the World's Columbian Exposition has been that it exemplified economic elitism, capitalism, racism and imperial ambitions. ${ }^{4} \mathrm{I}$ do not aim at critiquing or confirming this view, but rather to continue Warren Susman's argument that the early American World Expositions represented a "liminal stage," which offered an "opportunity to regroup and rethink the world ... that leads to an acceptance and participation in a new social order that is emerging technologically, socially, culturally and politically." 5 The period in-between the American Civil War and the Progressive Era could be seen as a final move away from Thomas Jefferson's vision of agrarian republicanism and towards Alexander Hamilton's vision of an urban society characterized by a strong centralized government, manufacturing and international trade. ${ }^{6}$ The Columbian Exposition was the most elaborate of a series of world fairs that Astrid Böger argues were "performative spectacles" for re-shaping

\footnotetext{
${ }^{2}$ Alan, Trachtenberg, The Incorporation of America: Culture and Society in the Gilded Age, (Hill and Wang, New York, 1982), 211.

${ }^{3}$ Trachtenberg, The Incorporation of America, 208.

${ }^{4}$ Henry, Adams, Education of Henry Adams, (Oxford, Oxford University Press, 2008), 288; Robert W. Rydell, All the World's a Fair: Visions of Empire at American International Expositions, 1876-1916, (Chicago, University of Chicago Press, 2013); Trachtenberg, The Incorporation of America, 208-234. ${ }^{5}$ Warren Susman: "Ritual Fairs," Chicago History 12, no. 3 (1983), 6; Henry Adams, Mont Saint Michel and Chartres, (New York, Penguin books, 1986), 103.

${ }^{6}$ Alexander Hamilton, Report on the Subject of Manufactures, sixth ed., (Philadelphia, William Brown, 1791) http://www.archive.org/details/alexanderhamilt00caregoog
} 
national identity. ${ }^{7}$ Beneath the performance of spectacle, however, is the power of imagination. As Cesare Silla points out, the Exposition "marketed and shaped an imaginary," as an attempt to communicate a new relationship between technology and the good society. ${ }^{8}$ In this article I will explore two intertwining lines of inquiry. First, how can visions of the good society be transmitted from the invisible world of the imagination to a visible and public world, and subsequently how does this process of transmission, organized through technological systems, establish a new foundation for speech, action and common sense?

At the end of his Travels in Hyperreality, Umberto Eco posited the theory that the prime objective of World Expositions was not to display individual artifacts and technologies, but rather to present the exposition as a whole - its setting, architecture and environs - in order to communicate "the image of civilization" and suggest its "experimental directions." 9 The Columbian Exposition, as well as other American Expositions in the same period, can be seen as attempts to create what Sheila Jasanoff and Sang-Hyun Kim refer to as sociotechnical imaginaries: "collectively held, institutionally stabilized, and publicly performed visions of desirable futures, animated by shared understandings of forms of social life and social order attainable through, and supportive of, advances in science and technology."10

Sociotechnical imaginaries involve four phases: "origins, embedding, resistance and extension," which refer, respectively, to the private imagination of an individual or small group; how this vision becomes public through the "coproduction" of "ideas, materiality, values and sociality;" how this in turn meets resistance from competing visions of the future; and how it can eventually extend beyond its original setting. ${ }^{11}$

Here my focus is limited to the phases of origins and embedding, the notion that private ideas "latch onto tangible things" that are public, and that this stage can be seen as involving the fabrication of a sociotechnical prototype-the tentative

\footnotetext{
${ }^{7}$ Astrid Böger, Envisioning the Nation: The Early American World's Fairs and the Formation of Culture (Frankfurt, Campus Verlag, 2010), 21, 285.

${ }^{8}$ Cesare, Silla, "Chicago World's Fair of 1893: Marketing the modern imaginary of the city and urban everyday life through representation" First Monday,Volume 18 Number 11 (25 November 2013)

${ }^{9}$ Umberto Eco, Travels in Hyperreality, (London, Picador, 1987), 299, 306.

${ }^{10}$ Sheila Jasanoff, and Sang-Hyun,Kim, "Containing the Atom: Sociotechnical Imaginaries and Nuclear Power in the United States and South Korea", Minerva 47: (2009), 120; Sheila Jasanoff and Sang-Hyun Kim, Dreamscapes of Modernity: Sociotechnical Imaginaries and the Fabrication of Power, (Chicago, University of Chicago Press, 2015), 4.

${ }^{11}$ Jasanoff and Kim, Dreamscapes of Modernity, 326-338.
} 
materialization of a sociotechnical vision. ${ }^{12}$ In other words, if it is true, as Dennis Gabor famously argued, that "the future cannot be predicted, but futures can be invented, "I will argue that like most other inventions, sociotechnical futures rely on blueprints and prototypes, which make them visible things in a public world, and that such cases might aid our prediction and evaluation of such potential futures. ${ }^{13}$

I look closer at the relationship between sociotechnical imaginaries and their materialization by invoking Hannah Arendt's political thinking and social ontology. Building on her theory of the relationship between the invisible private imagination, the visible public world, and the political phenomenon of public "speech and action," I further explore the notion of establishing shared understandings and common sense in relation to sociotechnical visions of the future. ${ }^{14}$ Reading across Arendt's investigations into The Human Condition, The Life of the Mind and her "Introduction to Politics," I look at the connection between private imagination, common things and public speech and action. I argue that her notion of context and common sense, in addition to metaphor, serves as the link between the private life of the mind and the public world of our human condition, and attempt to further clarify this argument by appealing to John Searle's notion of the background and Don Ihde's theory of background relations. ${ }^{15}$

This dual approach, on one side thinking about technology and on the other side political thinking, is inspired by Mark Coeckelbergh's essay "Technology and the good society: A polemical essay on social ontology, political principles, and responsibility for technology" in this issue.

Coeckelbergh argues that studies of the social impact of technology often suffer due to a presupposition of social atomism, which limits studies to " individual' artefacts and their relation to (individual) humans."16 This assumption, that societies are reducible to the sum of individuals, misses the fact that we are embedded in particular social orders and cultures, but also environments or settings, which to an increasing degree involve and are influenced by

\footnotetext{
12 Ibid, 326-338.

${ }^{13}$ Dennis Gabor, Inventing the Future, (London, Secker \& Warburg, 1963), 207.

${ }^{14}$ Hannah, Arendt, The Human Condition, 2.ed (Chicago: University of Chicago Press, 1998), 176.

15 Arendt, The Human Condition, 173.

${ }^{16}$ Mark Coeckelbergh, "Technology and the good society: A polemical essay on social ontology, political principles, and responsibility for technology", Technology in Society (This Issue), http://dx.doi.org/10.1016/j.techsoc.2016.12.002), 1.
} 
technological artifacts and systems. ${ }^{17}$ Thus, the challenge for those studying the relationship between the technological and the social is to take their underlying view of social ontology into consideration, but also, as far as "technologies raise political issues," to expand the horizon by taking political philosophy into view.

Addressing the interrelation between the social, the political and the technological further involves taking into account epistemic concerns as "technology changes not only individual thinking, but also always at the same time our society and our culture, including its values and indeed political principles. $" 18$ In other words, technological futures cannot be separated from social futures; philosophy of technology as well as political philosophy presupposes a social ontology; and technology can challenge our common sense and hence influence the political activities of public speech and action. Technological systems and artifacts can become centers of attention, gathering publics around themselves in a similar way to the spectators of a game. But, they can also make up less noticeable relational spaces, contexts in which people become encircled in a way similar to the role of the sports stadium including its underlying technological systems.

This relationship between central artifacts, context and enactment can arguably be found in in everyday situations. The IKEA showroom invites you to imagine how a piece of furniture might look in your current living room, but at the same time it encourages you to re-imagine how your future living room might look more like the IKEA showroom. It takes on the characteristics of a full-scale model of the potential future of your home, not simply by way of visual representation, but by allowing you to experience and encouraging you to enact its designer's vision of the future of private life. Similarly, as in the case of the White City of the Columbian Exposition, full-scale models of the public world can be seen as tentative materializations of sociotechnical imaginaries. Here people are encouraged not only to watch the spectacle of technological innovation, but invited into an environment in which they can experience and enact a particular vision of technology and the good society, in full-scale.

In order to discuss the connection between sociotechnical visions of the future and their transformation into full-scale models such as the Columbian

\footnotetext{
${ }^{17}$ Coeckelbergh, "Technology and the good society", 5.

${ }^{18}$ Ibid, 5.
} 
Exposition; I will draw upon Arendt's thinking on the relationship between invisible imagination and the public world. Before doing so I will briefly address some conflicting ways of evaluating such visions, based on Arendt's own premise that "in order to be what the world is always meant to be, a home for men during their life on earth, the human artifice must be a place fit for action and speech."19

\section{Politics for a good society, a good society for politics}

In the Human-Built World, Thomas P. Hughes considered how to think about technology and culture. He argued that we could think of it as: "craftsmen, mechanics, inventors, engineers, designers and scientists, using tools, machines and knowledge to create and control a human-built world consisting of artifacts and systems." ${ }^{20}$ One might argue that Hughes' definition does not adequately take into account the internal and hidden world of biotechnology, which to a certain degree deals with building humans to fit the world, rather than building a world to fit humans. ${ }^{21}$ But my point here is that if we see the world as built by and for humans, it cannot be seen from the perspective of the designer alone. It must implicitly or explicitly involve some definition of their coexistence in society and how they approach the classical political problem of finding a common good. How do competing visions of the good society influence what the human-built world, including its technological systems and artifacts, should be built for?

Phillip Brey argues in this issue that one way of approaching the relationship between technology and the good society would be to identify the "values for a good society," and further investigate how technology can aide us in their realization. By balancing the utilitarian happiness principle with John Rawls' liberal principle of justice as fairness, Brey defines well-being and justice as the "intrinsic values" for a

\footnotetext{
${ }^{19}$ Arendt, The Human Condition, 173.

${ }^{20}$ Thomas P. Hughes, Human-Built World: How to Think about Technology and Culture, (Chicago, The University of Chicago Press, 2004), 4.

${ }^{21}$ For further discussion on changing our natures see: Brian. D Earp, and Anders Sandberg, and Julian A. Savulescu, "Natural selection, childrearing, and the ethics of marriage (and divorce): Building a case for the neuroenhancement of human relationships." Philosophy \& Technology, 25(4) (2012), 561587. https://doi.org/10.1007/s13347-012-0081-8
} 
good society. ${ }^{22}$ These values are in turn supported by a set of "necessary instrumental values," freedom, democracy and sustainability, without which the former cannot be realized. ${ }^{23}$ Subsequently, "technology for a good society can be defined as technology that provides fundamental support for well-being and justice." 24 Brey admits that definitions of well-being and justice are open to interpretation and can be pursued in different ways "leading to different conceptions of the good society," but also that more extensive arguments can be developed in order to "defend a particular conception of a good society." 25 The danger inherent in the latter is that if a particular definition of well-being and justice becomes the foundation for a hegemonic view of the good society, there would no longer be any reason to sustain the necessary instrumental values that served as its precondition. ${ }^{26}$ In other words a vision of complete well-being and total justice, with no competing alternatives, would no longer require freedom and democracy as the realm in which the definition of the good society remains open to deliberation. A complete and all-encompassing definition of the good society might end in a totalitarian society.

Hannah Arendt's political thinking suggests an alternative to utilitarianism and modern liberalism, and hence questions the unconditional use of well-being and justice as values for the good society. In her "Introduction into Politics," Arendt argued that seeing politics as a means to higher ends, well-being or justice, is "precisely what politics is not." 27 She saw in modern politics the rise of a kind of "collective housekeeping," which sought to replace the private realm of the family and its property with the political economy and territory of the modern nation-state. With this rise of "society" and the image of the "super-human family" of the nation, the intrinsic values of the private household were becoming public concerns. ${ }^{28} \mathrm{By}$ contrast the private realm had traditionally been defined as a site in which labor secures bodily necessities, and property defines “one's location in a particular part of

\footnotetext{
${ }^{22}$ Phillip Brey, "The strategic role of technology in a good society", Technology in Society (2017), http://dx.doi.org/ 10.1016/j.techsoc.2017.02.002, (this issue), 3.

${ }^{23}$ Ibid, 3.

${ }^{24}$ Ibid, 4.

25 Ibid, 4,6.

${ }^{26}$ For further discussion on well-being see: Timothy Edwin, Taylor, "Towards Consensus on WellBeing”, in, Well-Being in Contemporary Society Ed., Søraker, J.H., Van der Rijt, J.-W., de Boer, J., Wong, P.-H., Brey, P., (Cham: Springer, 2015).

${ }^{27}$ Hannah Arendt, "Introduction into Politics," In The Promise of Politics, ed., Jerome Kohn, (New York: Schocken Books, 2005), 119, 194.

${ }^{28}$ Arendt, The Human Condition, 257,28.
} 
the world" as opposed to one's wealth. ${ }^{29}$ From the private realm individuals could venture into the public realm and take part in the political activities of public "speech and action." ${ }^{30}$ For Arendt, these activities were themselves equal to political freedom, which involved access and ability to participate in a "space of appearance" within a delineated public space. ${ }^{31}$ Consequently political action and political freedom is "primarily an end and not a means." 32 Politics are not the means to reach the ends of the good society; the good society is that in which people can enjoy political freedom. Subsequently, the human-built world, should be a "place fit for action and speech."33 Technological artifacts and systems should, as part of the public realm, create conditions under which political action and freedom can take place.

In her dismissal of well-being and re-distribution of social goods as the ends of politics, Arendt attempts to draw a clear distinction between the public and the private realm. It is a position that has attracted much criticism. In Human Being @ Risk, Coeckelbergh argues that this "sharp distinction between the immaterial sphere of freedom and politics and the material sphere of necessity," alongside the more general attempt to distinguish the private and the public realms, was both "misguided" and "futile." 34 But this critique overlooks Arendt's valorization of work that fabricates public things that in turn provides the setting or environment of "the common ... public realm. ${ }^{" 35}$ Public things can be distinguished from private necessities by both their production and their use. Necessities, such as bread or firewood, are the result of labor, which is repetitive and endless because bread or firewood are consumed and disappear when used. Things, such as mills and axes, are the result of work and have a "relative independence from men who produced and use them." ${ }^{36}$ Public things have different spatial and temporal qualities from private necessities as well as political speech and action. By “"standing still and remaining," people, "their ever-changing nature notwithstanding can retrieve their sameness, that is, their identity, by being

\footnotetext{
${ }^{29}$ Ibid, 61.

${ }^{30}$ Ibid, 176.

${ }^{31}$ Arendt, Human Condition, 198-200; Arendt, "Introduction into Politics", 123, 117

${ }^{32}$ Arendt, "Introduction into Politics", 117.

${ }^{33}$ Arendt, Human Condition, 173.

${ }^{34}$ Mark Coeckelbergh, Human Being @ Risk Enhancement, Technology and the Evaluation of Vulnerability Transformations, (Dordrecht Springer, 2013), 180.

${ }^{35}$ Arendt, Human Condition, 50; Hannah Arendt, The Life of the Mind, (San Diego: Harcourt, 1981), 20.

${ }^{36}$ Arendt, Human Condition, 137.
} 
related to the same chair and the same table." ${ }^{37}$ Publicly accessible things make up a "world of things," a common public realm in which speech and action is made possible and intelligible by constituting both a space to appear to others and a common sense of reality. ${ }^{38}$ Arendt's argument regarding the ends of the good society is not simply a dismissal of undeniable needs of human nature as political issues, but an argument regarding what can be experienced in common.

\section{Private imagination, public world, common sense}

Our experience of a common world of things marks the starting point for public life, but at the same time provides us with something to think about. In The Life of the Mind, Arendt presents a theory of reproductive imagination where imagination works in-between a public visible world of common things and our private invisible thinking. Imagination can be seen as the "capacity to transform sense-objects into images" as "elements from the visible world" are "de-sensed" and "rearranged...to create ... fictive entities in your mind." ${ }^{39}$ The images we produce are invisible to anyone else. Imagination is thus intrinsically private and needs some form of articulation or reification in order to be made public.

According to Arendt we have two possibilities for communicating to others what we privately imagine. One way is connected to public speech and our capacity to draw upon illustrative examples, "analogies, metaphors and emblems." ${ }^{40}$ Another approach is connected to the activity of work. Through "reification," the fabrication of what we imagine into a public thing, we have the opportunity to show rather than tell what we are thinking. ${ }^{41}$ Instead of describing a Ferris wheel as a large revolving wheel with many swing sets attached, we can fabricate a prototype, and publicly display what we privately imagine. Arendt's main point is that imagining both starts and ends in a common public world of things. Although this public world is common,

\footnotetext{
${ }^{37}$ Ibid, 137.

${ }^{38}$ Ibid, 52.

${ }^{39}$ Arendt, The Life of the Mind, 86, 85.

${ }^{40}$ Ibid, 109-110.

${ }^{41}$ Arendt, Human Condition,139,136. Arendt uses reification differently from that of the more common adaption of Marx by Peter L. Berger and Thomas Luckmann in The Social Construction of Reality. For Arendt reification does no imply "the apprehension of the products of human activity as if they were something else than human products," but rather the fabrication of objects, which become part of the "unending variety of things whose sum total constitutes the human artifice." see: Peter L. Berger and Thomas Luckmann The Social Construction of Reality; A Treatise in the Sociology of Knowledge, (London, Penguin Books, 1991), 106.
} 
it is at the same time inexhaustible from any single perspective and always perceived from a multitude of perspective: it thus "appears in the mode of it-seems-to-me." But it does provide us with a "sensation of reality," a shared context "that endows every single object with its particular meaning; and all other sense-endowed beings, though perceiving this object from utterly different perspectives, agree on its identity." This context, Arendt argues, "never appears entirely," but rather is "essentially mute" and "elusive." It is our "tacit acknowledgment" of the same context that provides us with a sense of reality although this reality can never be fully grasped. ${ }^{42}$

Our context is intrinsically connected to our "common sense." $"$ What is common cannot be located in the invisible capacities of thinking or our in subjective feelings of pain or pleasure, but rather depends on the existence of an external reality, a common world of durable things, which allows us to transcend the fact that objects within it appear via a multitude of individual perspectives. A public common world is the "decisive factor for intersubjective communication" as our speech and action is rendered intelligible by "corresponding to or following common sense." 44 In other words, without a durable world of things, there is no context providing a common sense of reality.

Above I argued that Eco's argument regarding World Expositions can be seen as involving the communication of sociotechnical imaginaries. If we now add Arendt's theory of the relationship between a tangible, durable, public world and the private, invisible realm of imagination, we see that in-between the stages of origins and embedding in Jasanoff and Kim's sociotechnical imaginaries, we must add a stage of reification: a materialization of what is privately imagined in order for there to be "publicly performed visions of desirable futures." ${ }^{45}$ With regards to the Columbian Exposition, the setting of things hardly qualifies as more than a quasiworld, made up of quasi-things due to its inherent lack of durability. Constructing a fake environment, a microcosm that gathers its visitors in a tentative public micropolis can be an effective way of creating the foundation of a public sphere. As I will argue below, it does so not by displaying single inventions and technologies, but by setting up a provisional context, which, albeit temporally limited, creates a shift in

\footnotetext{
${ }^{42}$ Arendt, The Life of the Mind, 38, 46-51.

${ }^{43}$ Arendt, The Life of the Mind, 52; Arendt, Human Condition, 57.

${ }^{44}$ Arendt, The Life of the Mind, 119.

45 Jasanoff and Kim "Containing the Atom: Sociotechnical Imaginaries and Nuclear Power in the United States and South Korea”,120; Jasanoff and Kim, Dreamscapes of Modernity, 4.
} 
common sense as it allows for a collective transformative experience - an enactment of the future in full-scale, which in turn allows for its re-imagining.

Changes in our context not only allow us to re-imagine the future, but also to talk about it in new terms. John Searle has argued that "efforts to communicate in a public language require that we presuppose a public world. And the sense of 'public' in question requires that a public reality exists independently of representations of that reality." Similar to Arendt's notion of context, public reality for Searle exists independently because it always appears to an "indefinitely large number of different points of view, different aspects and different conceptual systems," and thus "truth and reality cannot coincide." 46 If Searle's argument for external realism is similar to Arendt's notion of context, then his notion of background, "those abilities, capacities, dispositions, ways of doing things, and general know-how that enable us to carry out our intentions and apply our intentional states generally," can be seen as similar to Arendt's notion of common sense. ${ }^{47}$ Background capacities are taken for granted and thus support that which is not itself "part of the semantic content of the sentence."48 So when someone is asked to cut a cake they do not "run over it with a lawn mover." ${ }^{49}$ Knowing not to cut cakes with lawnmowers is not the result of complying with specific rules regarding cake-cutting in society, but is rather the result of social "norms of behavior" in virtue of which individuals develop taken-for-granted "capacities and abilities." 50

Searle argues that at least a minimum of background capacities needs to be shared in order for a society to work, while Arendt suggests that without a common sense of reality the world will be unfit for public speech and action. I will assert that changing the background - altering the context — can make a considerable impact on the intelligibility of public speech, but also on the way we imagine and deliberate about our future.

\section{Background relations and the good society at the Columbian Exposition}

\footnotetext{
46 John R. Searle, The Construction of Social Reality, (Penguin, London, 1995) 175187 186. Perhaps because of its elusive character, there seems to be multiple approaches to some notion of background in the Western history of ideas. Most notably in Martin Heidegger's notion of the ready-at-hand, but one might also include Charles S. Pierce's prejudices, or later Pierre Bourdieu's concept habitus.

${ }^{47}$ John R. Searle, Making the Social World: The Structure of Human Civilization, (Oxford, Oxford University Press, 2010), 31; Searle, The Construction of Social Reality, 129.

${ }^{48}$ Searle, The Construction of Social Reality, 130.

${ }^{49}$ Ibid, 130-131.

${ }^{50}$ Ibid, 147.
} 
In the 1893 meeting of the American Historical Association held in conjunction with the Columbian Exposition, Fredrick Jackson Turner announced that the frontier, as "the outer edge of the wave" that formed at "the meeting point between savagery and civilization" had collapsed on the shores of California. ${ }^{51}$ At the moment it subsided, it had metaphorically backwashed across the continent only to break again and to be reenacted in the construction of the Exposition's White City on the shores of Lake Michigan. This did not exactly replicate the conditions of American settlement, but it did reveal the process of building anew, including the representation of nature and culture.

The construction of the Exposition's fairgrounds happened in three stages, each providing one layer of what would eventually become its White City. In the spring of 1891, "earth-workers" began the effort to construct the foundation for the Exposition. As Director of Works Daniel Burnham described this process, the "undergrowth surrendered to the prosaic but effective grubbing hoe, and for the first time in their existence the knotty little scrub-oaks bowed - the ax is an inexorable tutor in the branch of etiquette."52 After nature had learned its lesson, Fredrick Law Olmstead and Calvert Vaux, who 20 years earlier had designed New York's Central Park, carefully transformed the "dreary landscape" into the picturesque Jackson Park fully equipped with "canals, lagoons and basins," islands, "grassy slopes ... flowers and shrubs." ${ }^{, 53}$

On top of this foundation, itself somewhere in-between wilderness and culture, notable architects and firms such as Louis H. Sullivan, Richard M. Hunt, Henry Ives Cobb, Charles B. Atwood, McKim, Meade \& White and Peabody \& Stearns were responsible for the design of the monumental buildings, which formed the full-scale model of the White City. Its largest structure, the Manufactures and Liberal Arts building was at the time the largest building in the world, "three times as large as St. Peters Church at Rome ... four times larger than the Coliseum."54 This, and the Exposition's thirty other main buildings were made to appear as if built of

\footnotetext{
${ }^{51}$ Frederick J. Turner, "The Significance of the Frontier in American History," in. Annual Report of the American Historical Association for the Year 1893, (Government Printing Office, Washington, 1894) http://www.archive.org/details/1893annualreport00ameruoft

52 Stuart C., Wade Rand McNally Handbook World's Fair (Rand, McNally \& Company, Publishers, Chicago, 1893), 24.

53 Ibid, 24.

${ }^{54}$ Ibid, 114.
} 
massive marble. In reality they were modern steel frames covered with a state-of-theart plaster-like material called "staff," a building technique that alluded to both the earlier American "balloon-house" and to the future of the modern skyscraper. ${ }^{55} \mathrm{In}$ between the buildings, staff was put to further use, as it became the material for the construction of sculptures and ornamentation. ${ }^{56}$

In addition to their size and material properties, the buildings expressed aesthetic unity and symbolic consistency. The 1876 Exposition in Philadelphia had displayed a chaotic mix of revival styles reflecting the American search for a national style in the $19^{\text {th }}$ century. Conversely, the 1893 Exposition in Chicago presented, with the notable exception of Louis Sullivan's Transportation Building, a harmonious display of Beaux-Arts architecture and neo-classical sculpture laid out in a perfectly planned symmetry and order. ${ }^{57}$ Henry Adams described his immediate experience of the Columbian Exposition as that of leaping "directly from Corinth and Syracuse and Venice, over the heads of London and New York." ${ }^{58}$ Its neo-classical exterior alluded to early American Greek revival architecture, Pierre Charles L'Enfant's plan of Washington D.C, to the history of great Republics and the political theology of John Winthrop's "city upon a hill." ${ }^{, 59}$ It marked the starting point of the City Beautiful movement in American city planning and architecture, especially visible in Burnham's MacMillian Plan of Washington D.C and the later Plan of Chicago, but also in the many civic landmarks built in the following decades. ${ }^{60}$

These two layers - the taming, cultivation, and representation of wilderness as picturesque nature and the construction of a built environment drawing from America's new (and temporary) appreciation for European high culture-enabled the fabrication of a world within which a tentative public could form. These two layers, or stages, also follow the rolling waves of Fredrick Jackson Turner's "frontier thesis"; the gradual transformation of the frontier where the hunter, then pioneer-farmer and later the entrepreneur "add field to field, clear out the roads ... build mills,

\footnotetext{
${ }^{55}$ Ibid, 25; Ted Cavanagh, "Balloon Houses: The Original Aspects of Conventional Wood-Frame Construction Re-examined", Journal of Architectural Education, 51:1, 5 .

${ }^{56}$ Wade, Rand McNally Handbook World's Fair, 25.

${ }^{57}$ Lewis, Mumford, Sticks and Stones: A study of American Architecture and Civilization, (New York: W.W.Norton \& Company, 1924) 130.

${ }^{58}$ Henry Adams, The Education of Henry Adams, (Oxford, Oxford University Press, 2008), 285.

${ }^{59}$ John Winthrop, "A Model of Christian Charity", in., The Norton Anthology of American Literature, $7^{\text {th }}$ ed., ed, Nina Baym, (New York, W.W.Norton \& Company, 200), 86 .

${ }^{60}$ Timothy J. Garvey, Public Sculptor: Lorado Taft and the Beautification of Chicago, (Chicago, University of Illinois Press, 1988); Mumford, Sticks and Stones, 127;Witold Rybczynski, Makeshift Metropolis: Ideas about Cities, (New York, Scribner, 2010), 26.
} 
schoolhouses, court-houses" turning wilderness into the village, which in turn "rises into a spacious town or city," into "a new product that is American."61 Technological innovation ran parallel to this development from the axe, the plough and the clearing of the forests of New England, by steam and railroad through the Great Plains, ending in the irrigated West. At the Exposition, Jackson declared the closing of the frontier, and with it the closing of "the first period in American history." 62 Turner standing at the brink of a new sociotechnical frontier, at the nexus of those new forces, which Henry Adams, then the president of the Historical Association, referred to as the "electro-dynamo-social universe," could not have chosen a better time for presenting his thesis. ${ }^{63}$ The Columbian Exposition marked the second period in American history.

The steam engine and the dynamo stood at the center of this new sociotechnical constellation, and together with staff, steel frames, sewage and water systems, it added an additional layer in-between cultivated nature and built environment. This network of pipes, cables, steel girders and pneumatic tubes, permeated the full-scale model of the White City. Allis steam engines and Westinghouse dynamos provided enough electricity to power the Exposition's 90,000 incandescent lamps, 5,000 arc lights and electric fountains, totaling more lights than any other city in America. ${ }^{64}$ The sewage collected from over 3,000 toilet rooms were transported by the Shone Hydro-Pneumatic System, treated with chemicals, pressed into solid cakes; later burned in an Engle Sanitary Garbage Cremator. Pumps supplied the fountains of the artificial lagoons with 40,000,000 gallons of water a day. ${ }^{65}$ And, due to a series of typhoid epidemics in Chicago, caused by bad sanitary conditions, the Exposition's sanitary engineers found it necessary to provide its own water supply. Hence, water was pumped through one hundred miles of piping from an external source above Lake Michigan, before it was cooled down and available through water dispensers throughout the grounds. ${ }^{66}$

\footnotetext{
${ }^{61}$ Turner, "The Significance of the Frontier in American History," 201, 213-214.

62 Turner, "The Significance of the Frontier in American History," 227.

${ }^{63}$ Adams, The Education of Henry Adams, 345.

${ }^{64}$ David E., Nye, Electrifying America: social meanings of a new technology, 1880-1940, (Cambridge, Mass: MIT Press, 1990), 37.

${ }^{65}$ Wade, Rand McNally Handbook World's Fair, 80; W. F. Morse, "Disposal of Waste at the World's Columbian Exposition." Science 22, no. 566 (1893): 316-17. http://www.jstor.org/stable/1766832.

${ }^{66}$ Meredith, Osborn, "Water, Typhoid Rates, and the Columbian Exposition in Chicago" Public Health Review, vol. 2, issue. 2 (2015)
} 
These modern technological systems established the Exposition's own context and environment separated from surrounding Chicago and the rest of the American continent. They created a new background for the normal understanding of utterances. By temporarily shifting context, they skewed common sense and thus gave the Exposition's visitors the opportunity to experience and enact its sociotechnical vision. This transformative experience furnished its tentative public with new images for the re-imagination of the relationship between technology and the good society.

Perhaps nowhere was this new phenomenon of technological systems inbetween nature and the built environment more explicitly represented than in the movable sidewalk, which transported visitors from the Exposition's pier into its White City. With the capacity to transport over 5,000 visitors at two different speeds, it literally swept them off their feet. ${ }^{67}$

In his experience of the Exposition, Adams found that it represented "a breach in continuity - a rupture in historical sequence!" as new technological systems covered in neo-classical plaster shells "gave history a new phase." 68 This experience and conclusion would later inspire his dynamic theory of history. At the nexus of this theory lay the notion that history was driven by forces towards increasing entropy, and that this movement happened in ever accelerating leaps. ${ }^{69}$ For Adams, his speech and action were, in Arendt's terms, "absorbed into the historical process" and thus occurred with or against "the flow of history." 70 Unlike Arendt, Adams failed to see history as the "story of events" driven by the speech and action of people; instead it stood for "forces or ideas with predictable courses." ${ }^{\text {71 }}$ For Arendt the public world of things creates a layer of stability in-between the "cyclical movement" of nature and the fleeting speech and actions of people. ${ }^{72}$ The moving sidewalk, the pneumatic sewage system and the electric grid, shook the foundations underneath Adams' feet. Together with the American people, he no longer flowed through the world like water through a stream; rather the world had now taken on the characteristics of the stream and he was swept along by its current. While "drifting unconsciously to some point,"

\footnotetext{
${ }^{67}$ Wade, Rand McNally Handbook World's Fair, 137.

${ }^{68}$ Adams, The Education of Henry Adams, 286.

${ }^{69}$ Ibid, 395-414.

${ }^{70}$ Arendt, "Introduction into Politics," 121.

${ }^{71}$ Arendt, Human Condition, 252.

72 Ibid, 137.
} 
Adams concluded that "nothing remained for a historian but to ask- how long and how far!"73

Ten years later at the Exposition in St. Louis, fairgoers would experience airplanes and automobiles, wireless telegraphy, and the newfound material radium. In 1915 San Francisco's Panama-Pacific International Exposition introduced the assembly line to the American public. ${ }^{74}$ When the Exposition returned to Chicago in 1933, the white neo-classical structures of the Columbian Exposition were replaced by modern windowless buildings fully equipped with artificial lighting and aircondition providing "constant control over both light and ventilation regardless of the kind or time of day." 75 One of its central features, the Fountain of Science, depicting a giant robot pushing a man and woman forward, replaced David Chester French's golden statue of the Republic, which had stood at the center of the Columbian Exposition's Court of Honor. ${ }^{76}$ President Cleveland's "monster industrial servant," which was set in motion by a single push of a button, was replaced by an "electric eye" automatically responding to the light from the star Arcturus that had begun its travel in space at the very moment of Cleveland's push 40 years earlier. ${ }^{77}$ These new automated technological systems supported the Exposition's slogan "Science finds, Industry Applies, Man Conforms." 78 The experience and recognition of the industrial slave at the Columbian Exposition prepared the American public for a new sociotechnical imaginary.

In his essay "Literal Meaning," Searle humorously uses the example of the "cat on the mat" by moving it into more or less absurd backgrounds. ${ }^{79}$ In the string of American Expositions at the turn of the $20^{\text {th }}$ century the meaning of the future became posited against new technological backgrounds. Unlike the constant movement at the American frontier, the American public now found itself in the midst of a world set in motion.

\footnotetext{
73 Arendt, "Introduction into Politics," 120; Adams, The Education of Henry Adams, 287,289.

${ }^{74}$ Böger, Envisioning the Nation, 193,249.

75 John Joseph, Flinn, Official guide to the World's Columbian Exposition, (Chicago, World's Columbian Exposition 1893), 22-23.

${ }^{76}$ Board of Control, World's Columbian Exposition Chicago, Dedicatory and opening ceremonies of the World's Columbian exposition: Historical and Descriptive. (Chicago: Stone, Kastler \& Painter, 1893) 259; Cheryl R., Ganz, The 1933 Chicago World's Fair: A Century of Progress (Chicago, University of Illinois Press, 2008, Kindle Edition), 56.

${ }^{77}$ Board of Control, World's Columbian Exposition Chicago, Dedicatory and opening ceremonies of the World's Columbian exposition:, 39, 265, 259, 266; Flinn, Official Guide: Book of the Fair, 20.

${ }^{78}$ Flinn, Official Guide: Book of the Fair, 11.

${ }^{79}$ John R. Searle, "Literal Meaning." Erkenntnis 13, no. 1 (1978), 207-24. http://www.jstor.org/stable/20010627.
} 
As Arendt has argued, without any temporally durable and spatially stable common things, our background would no longer contain a world, which "precede[s] one's own arrival and will survive one's own departure." ${ }^{80}$ We would enter into the cyclical movement of nature and loose the stabilizing function of things on our public speech and action. ${ }^{81}$ Something similar would happen in a hypothetical situation in which we became completely surrounded by commodities and those automated machines, which labor on our behalf. ${ }^{82}$

The Columbian Exposition can be seen as one example of how changes in our context and external reality might change the background for our common sense. Arendt's view of technology, as the means of creating and maintaining a human-built world, implies that such means are also part of the world itself. Arendt argues that "tools and instruments" are indeed "intensely worldly objects," but further distinguishes such tools from automated machines. ${ }^{83}$ Without going into a discussion of her claim that "the world of machines has become a substitute for the real world," I agree that they at least can form a substantial part of it. ${ }^{84}$

Today we are increasingly surrounded by machines that function independently of us, but affect our everyday lives nonetheless. One way of approaching this phenomenon is through Don Ihde's notion of technological background relations: "automatic and semiautomatic machines . . . which remain in the background or become a kind of near-technological environment itself." 85 The most obvious examples today are air-conditioning units, lighting, refrigerators, Wi-Fi networks and smart meters: technologies that are barely, if ever, noticeable in our everyday environments. However, once plugged into the taken-for-granted electrical

\footnotetext{
${ }^{80}$ Arendt, Human Condition, 50;Arendt The Life of the Mind, 20.

${ }^{81}$ Arendt, Human Condition, 137. See also: Bruno Latour, “On Interobjectivity”, Mind, Culture, and Activity 3, No. 4, (1996)

${ }^{82}$ Arendt, Human Condition, 152-153. An alternative to changing the context, or background, would be to change men and their nature. In other words by way of biotechnology it is not unlikely that one might change the five senses of some humans so much that there would no longer be any hope of common sense. Arendt notes this in in the prologue to The Human Condition in the notion of altering the "size, shape and function" of humans. The equivalent in Searle would be to radically change what he defines as the "local background... common to all human beings in virtue of their biological makeup — capacities such as walking, eating, grasping, perceiving, recognizing” John R. Searle Intentionality: an essay in the Philosophy of Mind: (Cambridge University Press, Cambridge, 1983), 144.

${ }^{83}$ Arendt, Human Condition, 144, 147.

${ }^{84}$ Ibid, 152. For further analysis of Arendt's view on automation, see: Brian Simbirski. "Cybernetic Muse: Hannah Arendt on Automation, 1951-1958." Journal of the History of Ideas 77, no. 4 (2016): 589-613. https://muse.jhu.edu/ (accessed 17. March, 2017)

${ }^{85}$ Don Ihde, Technology and the Lifeworld: From Garden to Earth, (Bloomington, Indiana University Press, 1990), 108.
} 
grid, they "no less than focal ones, transform the gestalts of human experience and, precisely because they are absent presences, may exert more subtle indirect effects upon the way a world is perceived. " 86

Similar to what Albert Borgmann later called the "device paradigm," Arendt sees semi-automated background relations transcending technology as "servants of the hand" or the machine to which the laborer "adjusts the natural rhythm of his body." ${ }^{87}$ In the case of automation, the machine can become so deeply embedded in the environment that they determine this rhythm without any apparent movement or audible beat. In States of Knowledge, Jasanoff argues that "in engagements with the physical world, we are not mere spectators ... we tune into the rhythms of everyday life." 88 As technology becomes a more prominent part of everyday life, it, in Arendt's words, replaces the "cyclical movement of nature's household." 89 If technological systems and artifacts increasingly slip into the background they gradually become "a substitute for the real world" as they are "transplanted in an ever-increasing measure into the environment of man." If "technology no longer appears," but rather takes on the characteristics of natural forces, man would need to adjust to machines in the same way as he previously adjusted to nature..$^{90}$

The technological systems supporting the White City at the Columbian Exposition were one of the first examples of the new rhythm of American modernity. Its millions of visitors put on their best clothes and took to the dance floor. Henry Adams stood in a corner watching, while reluctantly tapping his foot to the beat.

\section{Conclusion}

In this paper I have attempted to take up Mark Coeckelberg's challenge to move beyond the relationship between individual artifacts and individual humans by investigating how technology impacts society, culture, and the political. Seeing the World's Columbian Exposition in light of its social and economic context and Arendt's political thinking and social ontology, I have argued that it attempted to communicate its own vision of the good society by creating a full-scale model

\footnotetext{
${ }^{86}$ Ihde, Technology and the Lifeworld, 112.

${ }^{87}$ Albert. Borgmann, Technology and the Character of Contemporary Life: A Philosophical Inquiry (Chicago, University of Chicago Press. Kindle Edition, 1984),40; Arendt, Human Condition, 147.

${ }^{88}$ Sheila Jasanoff, "Ordering knowledge, ordering society", in., Stated f Knowledge, The co-production of science and social order,ed., Sheila Jasanoff, (London, Routledge, 2004) 16.

${ }^{89}$ Arendt, Human Condition, 137.

${ }^{90}$ Ibid, 150-153.
} 
complete with its own technological background conditions, which further enabled and guided the imagination of its tentative public. Seen from a distance, this event, together with other American World Expositions at the turn of the $20^{\text {th }}$ century, prepared the American public for the second industrial revolution and confirmed Alexander Hamilton's vision of American national identity as capitalistic and industrial.

Arendt's view on technological artifacts and systems can be seen in conjunction with Ivan Illich's tools for conviviality or Borgmann's things or devices, but despite her thinking about technology she is principally a political thinker. ${ }^{91}$ Arendt's thinking is relentlessly directed towards the notion of political freedom, and thus offers a simple standard for evaluating the relationship between technology and the good society: do technological systems and artifacts enhance or limit the possibility of public speech and action? Do they, as part of a world of things, provide the necessary epistemological, temporal and spatial stability, which in turn furnishes our common sense of reality on top of which our private imagination and public deliberation takes place?

Today information and communications technology is increasingly becoming part of our contexts. On one side there is social media, represented by smartphones, laptops and their various interfaces and applications. On the other side, there is the notion of an Internet of things, were everyday artifacts become interconnected via the Internet. Both come with their set of potential challenges to the world as a place fit for human speech and action.

One potential development, as Luciano Floridi has argued, is that we are gradually "enveloping the environment into an ICT-friendly infosphere" where "the distinction between online and offline will become ever more blurred and then disappear" eventually leading to a condition in which we "accept the virtual as partly real and the real as partly virtual." 92 If the world were to become fit for technology, rather than human speech and action, this would fundamentally alter how we speak and act. If otherwise inanimate things are animated - as precluded by theories of actants and vibrant materiality and epitomized in the concept and increasing reality of

\footnotetext{
${ }^{91}$ Ivan, Illich, Tools for Conviviality,(Calder \& Boyars, London, 1973); Lewis, Mumford,. "Authoritarian and Democratic Technics." Technology and Culture 5, no. 1 (1964): 1-8. doi:10.2307/3101118.; Albert, Borgmann, Technology and the Character of Contemporary Life: A Philosophical Inquiry (Chicago, University of Chicago Press. Kindle Edition, 1984), 40. ${ }^{92}$ Luciano Floridi, The $4^{\text {th }}$ Revolution: How the Infosphere is reshaping Human Reality (Oxford University Press, Oxford, 2014), 144,43,218.
} 
the Smart City - this could seriously impede on the formation of a sense of reality, which relies on things "“standing still and remaining' the same long enough to become an object for acknowledgement and recognition by a subject." $" 93$

Another possible issue is that we might prefer and prioritize the images of our screens over our experience and embodiment in a world of things. We might as a consequence end up like Mary in Frank Jackson’s famous thought experiment, "forced to investigate the world" of color "from a black and white room via a black and white television monitor." "In other words, if we were to retreat into the private sphere, we might still have access to "physical information" about the public world, via projects like Wikipedia, and we might even deliberate upon such information via social media, but we would lack the experience of those things, that despite all technical and scientific description, nonetheless "appears in the mode of it-seems-tome." ${ }^{95}$ As information and intersubjective communication on the World Wide Web increasingly intervenes in the web of human relationships, it might paradoxically leave us devoid of those experiences, which provide our private imagination with material and our public deliberation with something to talk about, and hence seriously erode our common sense of reality.

These are arguably extreme cases and evaluating their impact seems limited to our imagination. What I have proposed by looking at the Columbian Exposition is that sociotechnical imaginaries sometimes reveal themselves in full-scale before being fully implemented into society, as sociotechnical prototypes. Where do we find examples of such environments today? If the answer is the controlled and monitored environments of submarines, airplanes and space stations, which Peter Sloterdijk has referred to as "absolute islands," one should also note that such super-efficient environments, at least to my knowledge, always involve authoritarian hierarchies between captains and crews rather than open political spaces subject to processes of deliberation. ${ }^{96}$ If the human-built world, including its technological systems and artifacts, is ultimately meant to be fit for sustaining life in a life-threatening environment, and if our environment is increasingly becoming life-threatening, perhaps alternative sociotechnical prototypes can be found in the more earthbound

\footnotetext{
${ }^{93}$ Arendt, Life of the Mind, 45-46.

${ }^{94}$ Frank Jackson, "Epiphenomenal Qualia." The Philosophical Quarterly (1950-) 32, no. 127 (1982): 127-36. doi:10.2307/2960077, 130 .

${ }_{95}$ Arendt, The Life of the Mind, 38.

${ }^{96}$ Peter Sloterdijk, Spheres Volume 3:Foams, Plural Sphereology, trans Wieland Hoban (South Pasadena CA, Semiotext(e), 2016), 294.
} 
environments of the hospital isolation wards, or the nuclear bunker. If mere life is not enough to determine the goal of our technology, we should perhaps instead look to environments that provide well-being and happiness, and perhaps the cruise ship or the amusement park provide better prototypes for the good society. If we cannot imagine a good society within such environments, perhaps it is time to look for alternative sociotechnical prototypes, which might provide us with the material for building a world better fit for public speech and action. 


\section{Sources:}

Adams, Henry, Education of Henry Adams, Oxford: Oxford University Press, 2008

Adams, Henry Mont Saint Michel and Chartres, New York: Penguin books, 1986

Arendt , Hannah, “Introduction into Politics,” In The Promise of Politics, ed., Jerome Kohn, New York: Schocken Books, 2005

Arendt, Hannah, The Human Condition, 2.ed Chicago: University of Chicago Press, 1998

Arendt, Hannah, The Life of the Mind, San Diego: Harcourt, Inc, 1981

Berger, Peter L., and Luckmann Thomas The Social Construction of Realtity; A Treatise in the Sociology of Knowledge, London: Penguin Books, 1991

Board of Control World's Columbian Exposition Chicago, Dedicatory and opening ceremonies of the World's Columbian exposition: Historical and descriptive. (Chicago: Stone, Kastler \& Painter, 1893) https://archive.org/details/dedicatoryopenin00worl

Borgmann, Albert. Technology and the Character of Contemporary Life: A Philosophical Inquiry, Chicago: University of Chicago Press, 1984, Kindle Edition

Brey, Phillip, "The strategic role of technology in a good society", Technology in Society (2017), http://dx.doi.org/ 10.1016/j.techsoc.2017.02.002), (this issue)

Böger, Astrid Envisioning the Nation: The Early American World's Fairs and the Formation of Culture, Frankfurt: Campus Verlag, 2010

Cavanagh, Ted (1997) "Balloon Houses: The Original Aspects of Conventional Wood-Frame Construction Re-examined", Journal of Architectural Education, 51:1, 5-15

Coeckelbergh, Mark, “Technology and the good society: A polemical essay on social ontology, political principles, and responsibility for technology" Technology in Society (2016), http://dx.doi.org/10.1016/j.techsoc.2016.12.002), (this issue)

Coeckelbergh, Mark Human Being @ Risk Enhancement, Technology, and the Evaluation of Vulnerability Transformations, Dordrecht: Springer, 2013

Earp, Brian. D, Sandberg, Anders, \& Savulescu, Julian. Natural selection, childrearing, and the ethics of marriage (and divorce): Building a case for the neuroenhancement of human relationships. Philosophy \& Technology 25, no. 4 (2012). 561-587. https://doi.org/10.1007/s13347012-0081-8

Eco, Umberto, Travels in Hyperreality, London: Picador, 1987

Flinn, John Joseph, Official guide to the World's Columbian exposition, Chicago: World's Columbian Exposition, 1893

Floridi, Luciano, The $4^{\text {th }}$ Revolution: How the Infosphere is reshaping Human Reality, Oxford: University Press, Oxford, 2014

Ganz, Cheryl R.,The 1933 Chicago World's Fair: A Century of Progress, Chicago: University of Illinois Press, 2008 
Garvey, Timothy J., Public Sculptor: Lorado Taft and the Beautification of Chicago, Chicago: University of Illinois Press, 1988

Gilbert, James Perfect Cities: Chicago's Utopias of 1893, Chicago: University of Chicago Press, 1991

Hamilton, Alexander, Report on the Subject of Manufactures, sixth ed., Philadelphia: William Brown, 1791, http://www.archive.org/details/alexanderhamilt00caregoog

Hughes, Thomas P., Human-Built World: How to Think about Technology and Culture, Chicago: The University of Chicago Press, 2004

Ihde, Don, Technology and the Lifeworld: From Garden to Earth, Bloomington,:

Indiana University Press, 1990

Illich Ivan, Tools for Conviviality,(Calder \& Boyars, London, 1973)

Jackson, Frank. "Epiphenomenal Qualia." The Philosophical Quarterly (1950-) 32, no. 127 (1982): 127-36. doi:10.2307/2960077. 127-136

Jasanoff, Sheila and Kim Sang-Hyun,"Containing the Atom: Sociotechnical Imaginaries and Nuclear Power in the United States and South Korea", Minerva 47, (2009)

Jasanoff, Sheila and Kim Sang-Hyun, ed., Dreamscapes of Modernity: Sociotechnical Imaginaries and the Fabrication of Power, Chicago: University of Chicago Press, 2015

Jasanoff, Sheila,"Ordering knowledge, ordering society", in., Stated f Knowledge, The co-production of science and social order, ed., Sheila Jasanoff, London: Routledge, 2004

Latour, Bruno, “On Interobjectivity”, Mind, Culture, and Activity, Volume3, No. 4, 1996

Morse, W. F., "Disposal of Waste at the World's Columbian Exposition." Science 22, no. 566 (1893):

316-17. http://www.jstor.org/stable/1766832.

Mumford, Lewis, Sticks and Stones: A study of American Architecture and Civilization, New York: W.W.Norton \& Company, 1924

Mumford, Lewis. "Authoritarian and Democratic Technics." Technology and Culture 5, no. 1 (1964): 1-8. doi:10.2307/3101118

Mumford, Lewis, The Pentagon of Power, New York, Harcourt, Brace Jovanovich, 1970

Nye, David E., Electrifying America : social meanings of a new technology, 1880-1940,

Cambridge, Mass: MIT Press, 1990

Osborn, Meredith, "Water, Typhoid Rates, and the Columbian Exposition in Chicago" Public Health Review, vol. 2, issue. 2 (2015)

Rydell, Robert W. All the World's a Fair: Visions of Empire at American International Expositions, 1876-1916,Chicago: University of Chicago Press, 2013

Rybczynski, Witold, Makeshift Metropolis: Ideas about Cities, New York: Scribner, 2010

Searle, John R., The Construction of Social Reality, London: Penguin,1995

Searle, John R. "Literal Meaning." Erkenntnis (1975-) 13, no. 1 (1978): 207-24.

http://www.jstor.org/stable/20010627.

Searle, John R.,Making the Social World: The Structure of Human Civilization, Oxford: Oxford University Press, 2010 
Searle John R. Intentionality: an essay in the Philosophy of Mind, Cambridge: Cambridge University Press, 1983

Simbirski, Brian, "Cybernetic Muse: Hannah Arendt on Automation, 1951-1958." Journal of the History of Ideas 77, no. 4 (2016): 589-613

Silla, Cesare. "Chicago World's Fair of 1893: Marketing the modern imaginary of the city and urban everyday life through representation" First Monday [Online], Volume 18 Number 11 (25 November 2013)

Sloterdijk, Peter, Spheres Volume 3:Foams, Plural Sphereology, trans Wieland Hoban, South Pasadena CA: Semiotext(e), 2016

Susman, Warren: "Ritual Fairs," Chicago History 12, no. 3 (1983),

Taylor, Timothy Edwin, "Towards Consensus on Well-Being”, in, Well-Being in Contemporary Society Ed., Søraker, J.H., Van der Rijt, J.-W., de Boer, J., Wong, P.-H., Brey, P., Cham: Springer, 2015

Turner, Frederick J., "The Significance of the Frontier in American History,” in. Annual Report of the American Historical Association for the Year 1893, Washington: Government Printing Office, 1894 http://www.archive.org/details/1893annualreport00ameruoft

Trachtenberg, Alan, The Incorporation of America: Culture and Society in the Gilded Age, New York: Hill and Wang,1982

Wade, Stuart C., Rand McNally Handbook World's Fair, Chicago: Rand, McNally \& Company, 1893

Winthrop, John, “A Model of Christian Charity”, in., The Norton Anthology of American Literature, $7^{\text {th }}$ ed.,Nina Baym, New York: W.W.Norton \& Company, 2008 